\title{
Caspase-8 in Labeo rohita is evolutionary conserved and is activated in Aeromonas hydrophila and Edwardsiella tarda infection and rhabdovirus vaccination
}

\author{
Mrinal Samanta*, Alok Kumar Giri, Mahismita Paichha, Pushpa Choudhary and Ashis Saha
}

\begin{abstract}
Background: Caspase-8, a member of the family of conserved cysteine proteases, plays a crucial role in the initiation phase of the apoptotic death-signaling cascade and thereby attracts interest for its study across the animal species including fish. In India, rohu (Labeo rohita) is an important freshwater fish species; thus, this study on caspase-8 was undertaken to investigate its role during pathogenic invasion.

Results: The complete cDNA sequence of Labeo rohita caspase-8 (Lrcasp8) consisted of 1746 bp nucleotides ( $\mathrm{nt}$ ) having an ORF of 1440 nt encoding a polypeptide of 480 amino acid (aa) residues with the molecular mass of $\sim$ $54.8 \mathrm{kDa}$. Structurally, Lrcasp8 comprised two DED domains (DED1 ${ }^{1-77 a a}$ and DED2 ${ }^{97-174 a a}$ ) and one CASC domain ${ }^{230-476 a a}$. Within the CASc domain, various putative motifs, viz., a large subunit (p20237-360aa), a small subunit $\left(\mathrm{p} 10^{389-474 a a}\right)$, and a penta-peptide (QACQG $\left.{ }^{354-358 a a}\right)$ active site, were identified. The secondary structure of Lrcasp8 protein comprised seventeen a-helices, eleven $\beta$-strands, and twenty-nine coils. Phylogenetically, it is closely related to common carp caspase- 8 and exhibits significant $(p<0.05)$ similarity $(88.3 \%)$ and identity $(78.7 \%)$ in their amino acid sequence. The tissue-specific expression of Lrcasp8 has been analyzed by quantitative real-time PCR assay, and it revealed the highest expression ( $\sim 23$-fold) in the blood and lowest in the spleen. In Aeromonas hydrophila and Edwardsiella tarda infection and rhabdovirus vaccination, caspase-8 gene expression in rohu fingerlings was significantly $(p<0.05)$ induced in various organs/tissues. Infection of the Labeo rohita gill cells with $A$. hydrophila resulted in apoptosis and cell death with the induction of caspase-8 gene expression.

Conclusion: This is the first report on the identification and structural characterization of caspase-8 cDNA and predicted protein and the analysis of caspase-8 gene expression in Labeo rohita following Aeromonas hydrophila and Edwardsiella tarda infections and rhabdovirus vaccinations. The data in this article together suggest the critical role of caspase-8 during infection and apoptosis in Labeo rohita.
\end{abstract}

Keywords: Indian major carps, Labeo rohita, Apoptosis, Caspase-8

\footnotetext{
* Correspondence: mrinal.samanta@icar.gov.in

Immunology Laboratory, Fish Health Management Division, Indian Council of Agricultural Research-Central Institute of Freshwater Aquaculture,

Kausalyaganga, Bhubaneswar, Odisha 751002, India
}

\section{Springer Open}

() The Author(s). 2020 Open Access This article is licensed under a Creative Commons Attribution 4.0 International License, which permits use, sharing, adaptation, distribution and reproduction in any medium or format, as long as you give appropriate credit to the original author(s) and the source, provide a link to the Creative Commons licence, and indicate if changes were made. The images or other third party material in this article are included in the article's Creative Commons licence, unless indicated otherwise in a credit line to the material. If material is not included in the article's Creative Commons licence and your intended use is not permitted by statutory regulation or exceeds the permitted use, you will need to obtain permission directly from the copyright holder. To view a copy of this licence, visit http://creativecommons.org/licenses/by/4.0/. 


\section{Background}

The program cell death or apoptosis (Kerr et al., 1972) is an energy-dependent highly ordered biochemical process characterized by distinct morphological changes. It is carried out by intra-cellular cysteine aspartyl specific proteases collectively known as caspases. To date, 12 caspases in humans (caspase-1-10, 12, and 14) and 18 caspases in other vertebrates (caspase-1-18) have been identified. On the basis of structural and functional similarities, these caspases are primarily grouped into two types: (1) inflammatory caspases (caspase-1, 4, 5, and 12) and (2) apoptotic caspases (caspase-2, 3, and 6-10). Members of the apoptotic caspase family are further subdivided as the upstream or initiator caspases comprising caspase-2, 8, 9, and 10 and the downstream or effector caspases comprising caspase-3, 6, and 7 (Salvesen et al., 1997; Spead et al., 2018).

Caspase-8, also recognized as "FLICE/MACH1/Mch5, " possesses a stretched prodomain consisting of death effector domains (DEDs) at the $\mathrm{N}$-terminal and a carboxyl-terminal catalytic domain (CASc) having p20 (large subunit) and p10 (small subunit) subunits (Shinichi et al., 2007). In the extrinsic apoptotic signaling pathway, caspase-8 associates with the Fas-associated protein with death domain (FADD) to form the deathinducing signaling complex (DISC) and then triggers the caspase- 3 for the apoptosis of the cells (Kischkel et al., 1995; Jost et al., 2009; Ashkenazi et al., 2008). The Fas-mediated apoptosis is hampered in cells which are deficient in caspase-8 (Kawahara et al., 1998). In addition to the extrinsic apoptotic pathway, caspase- 8 is also involved in the intrinsic apoptotic pathway with the cleavage and activation of BID protein (Luo et al., 1998). When truncated BID protein translocates to the mitochondria, it then activates the release of cytochrome $\mathrm{c}$ into cytosol resulting in the activation of Apaf-1/caspase-9 apoptosome (Li et al., 1997; Kuwana et al., 1998). The activated caspase- 9 triggers other downstream caspases for the apoptosis. In addition to the apoptotic signal, caspase- 8 is also involved in nonapoptotic functions such as embryonic development, monocyte differentiation, $\mathrm{T}$ and $\mathrm{B}$ cell proliferation, and NF- $\mathrm{B}$ activation (Maelfait et al., 2008). In humans, although caspase- 8 has been reported to act as a tumor suppressor, but conclusive evidence is still lacking (Teitz et al., 2000).

Compared to mammals, the work on caspase- 8 is restricted only to few fish species (Sakamaki et al., 2007). In the Atlantic salmon, 14 caspase genes of mammalian equivalent have been reported (Takle and Anderson, 2007). In the sea bass (Dicentrarchus labrax L.), caspase- 8 gene has been cloned and its inductive expression in the spleen has been observed in Photobacterium damselae ssp. piscicida (Phdp) infection (Reis et al., 2010). In the Wuchang brim (Megalobrama amblycephala) (Sun et al., 2015) and in the big-belly seahorse (Hippocampus abdominalis) (Oh et al., 2016), caspase-8 gene has also been cloned and characterized.

In India, rohu (Labeo rohita) is an economically important and widely cultivated freshwater fish species. To date, information on caspases is very limited in this fish. To prevent diseases, understanding the mechanism of pathogenesis and apoptosis is very important. Considering these, caspase- 8 in rohu has been cloned, its putative motifs have been identified, and modulation of its gene expression in various tissues has been investigated in bacterial infections and rhabdovirus vaccinations.

\section{Materials and methods Ethics statement}

In this study, the use of rohu (Labeo rohita) fingerlings for all experimental purposes including bacterial infection was approved (approval number, ICAR-CIFA/Eth/02/2016) by the Ethics Committee of the ICAR (Indian Council of Agricultural Research)-Central Institute of Freshwater Aquaculture (CIFA), Government of India. During the experiment, fishes were maintained with good husbandry practices, and to minimize pain, all fishes in the control and treated group were first anesthetized with MS222 (Tricaine methanesulphonate, Himedia, India, cat no: RM2178) and then were dissected for the collection of samples.

\section{Fish}

Rohu fingerlings (avg. wt $\sim 50$ g) were collected from the ICAR-CIFA farm and were kept in 500L aerated fiberreinforced plastic (FRP) tanks having the average water temperature $\sim 28{ }^{\circ} \mathrm{C}$ and $\mathrm{pH} \sim 7.5$. Before the start of experiment, all fishes were acclimatized in the FRP tanks for $\sim 4$ weeks with daily $1 / 3$ water exchange and were fed once in a day with the commercial carp diet.

\section{Bacterial strains}

In rohu, caspase- 8 gene expression in bacterial infections were examined with Aeromonas hydrophila (ATCC35654) and Edwardsiella tarda (ATCC-15947) infections. In short, these bacteria were grown in LB medium at $30{ }^{\circ} \mathrm{C}$ for overnight, and then, centrifugation was carried out at $5000 \mathrm{rpm}$ for $5 \mathrm{~min}$ followed by washing of the pellet with phosphate-buffered saline (PBS, pH 7.2), and then finally, the pellet was diluted in PBS. Fishes in the control group were intra-peritoneally (i.p.) injected with $100 \mu \mathrm{l}$ of PBS, and those in the treated group were i.p. injected with $100 \mu \mathrm{l}$ of PBS containing either $A$. hydrophila $\left(1 \times 10^{6} \mathrm{CFU} /\right.$ fish $)$ or E. tarda $\left(3 \times 10^{6} \mathrm{CFU} /\right.$ fish) (Basu et al., 2016; Sadangi et al., 2020). After 24, 48, and $72 \mathrm{~h}$ of infection, the gill, liver, kidney, spleen, and blood from the control and treated group of fishes were collected in TRIzol reagent for RNA extraction and caspase- 8 gene expression analysis. 


\section{Rhabdovirus vaccination}

To investigate the role of caspase- 8 in viral vaccination, an inactivated rhabdovirus vaccine (DEFENCER ${ }^{\circ} 1$, Zoetis, USA, cat. no. M149007) was i.p. injected at $100 \mu \mathrm{l} /$ fish and the control group of fishes was i.p. injected with $100 \mu \mathrm{l}$ $\mathrm{PBS} /$ fish. At 24,48 , and $72 \mathrm{~h}$ post-vaccination, the gill, liver, kidney, spleen, and blood from the fishes of control and treated groups were collected in TRIzol reagent for RNA extraction and caspase-8 gene expression analysis.

\section{RNA isolation and CDNA synthesis}

RNA extraction from tissue/cell culture samples was carried out following the protocol of TRIzol reagent (Invitrogen, USA). In each sample, RNA concentration was measured by UV-spectrophotometer (BioPhotometer plus, Eppendorf, Germany) and the quality was examined by analyzing $1 \mu \mathrm{g}$ of RNA/sample in agarose gel (1\%) electrophoresis. For cDNA synthesis, $1 \mu \mathrm{g}$ RNA was treated with $1 \mathrm{U}$ of DNase I (MBI, Fermentas, USA) and reverse transcription was carried out using RevertAid 1st strand cDNA synthesis kit with oligo-dT primer (MBI, Fermentas, USA).

\section{Real-time PCR analysis}

The quantitative real-time PCR (qRT-PCR) analysis of caspase- 8 and $\beta$-actin (housekeeping) gene was executed in Light Cycler 480 II-real time PCR detection system (Roche, Germany). The qRT-PCR reaction was carried out in a duplicate well of 96-well plate, and in each well, $10 \mu \mathrm{l}$ reaction mixture contained the following reagents: $5 \mu \mathrm{l} \mathrm{cDNA}$ as template, $0.25 \mu \mathrm{l}$ each of FW and RV primers, $2.5 \mu \mathrm{l}$ of $2 \times$ lightCycler 480 SYBR Green I master mix (Roche, Germany, cat no. 04707516001), and $2 \mu \mathrm{l}$ PCR grade water. The qRT-PCR was operated with the following cycling parameters: initial denaturation at $95^{\circ} \mathrm{C} /$ $10 \mathrm{~min}, 45$ cycles of denaturation at $95^{\circ} \mathrm{C} / 10 \mathrm{~s}$, annealing at $55^{\circ} \mathrm{C} / 10 \mathrm{~s}$, and extension at $72^{\circ} \mathrm{C} / 10 \mathrm{~s}$. Crossing-point (CP) values and melting curve analysis were carried out after the completion of PCR, and samples were loaded in $2 \%$ agarose gel to check specificity of the amplified PCR products. Relative quantification of the target gene (caspase- 8 ) with the reference gene ( $\beta$-actin) was calculated by using the $2^{-\triangle \Delta C T}$ method (Livak et al., 2001). Results obtained from qRT-PCR were expressed as mean \pm standard error.

\section{Statistical analysis}

The significant difference $(p<0.05)$ in caspase- 8 gene expression between the control and treated fish groups was determined by the statistical software SPSS v16.0.

Table 1 Primers, their sequence, and application in this study

\begin{tabular}{|c|c|c|}
\hline Primer & Sequence $\left(5^{\prime} \rightarrow 3^{\prime}\right)$ & Application \\
\hline \multicolumn{3}{|c|}{ (a) Primers used for PCR amplification and cloning of rohu caspase-8 } \\
\hline Casp8-FW" & CCAGCTGAAGTTTCTGTGC & Cloning \\
\hline Casp8-RV\# & CCGAGATTGTCTTCTGTCATGTC & \\
\hline Casp8-FW & AMTATCTGAAGACATGACAGAAGA & \\
\hline Casp8-RV\# & CCCS TAGAGGR AGTCTGCCTCCT & \\
\hline Casp8-FW* & GGGCACAGTGTTGGGTATTGAT & \\
\hline Casp8-RV* & GTGCTCTACTGTGGCCATTCCTA & \\
\hline GSP-RV-5' & CCTTGTTCCTGGGCCCTGTAGTCCTGTATCCT & 5'RACE \\
\hline GS-NP-RV-5' & GAGGCGTCACGTTGTTGCAGATTTCTTTCCAC & 5' Nested RACE \\
\hline GSP-FW-3' & TGACAAAGGTAAACCATGAAGTGAGCT & 3'RACE \\
\hline GS-NP-FW-3' & CAGTGTTGGGTATTGATGCTAAAGAGGTTGA & 3' Nested RACE \\
\hline \multirow[t]{2}{*}{ UPM } & $\begin{array}{l}\text { Long: CTAATACGACTCACTATAGGGCAAGCAGT } \\
\text { GGTATCAACGCAGAGT }\end{array}$ & RACE \\
\hline & Short: CTAATACGACTCACTATAGGGC & \\
\hline NUP & AAGCAGTGGTATCAACGCAGAGT & Nested RACE \\
\hline \multicolumn{3}{|c|}{ (b) Primers used for rohu-caspase-8 gene expression analysis by quantitative real-time PCR (qRT-PCR) assay } \\
\hline Casp-8 FW & GGGCACAGTGTTGGGTATTGAT & Real-time PCR \\
\hline Casp-8 RV & GTGCTCTACTGTGGCCATTCCTA & \\
\hline$\beta$-actin FW & AGACCACCTTCAACTCCATCATG & \\
\hline$\beta$-actin RV & TCCGATCCAGACAGAGTATTTACGC & \\
\hline
\end{tabular}

Primers marked with "\#” were designed from the conserved regions of caspase-8 cDNA sequence of Danio rerio (acc. no. AF273220.1), Ctenopharyngodon idella (acc. no. KP145003.1), and Cyprinus carpio (KC822471.1), and primers "** have been designed from the transcriptome sequence of rohu caspase-8. "M" stands for $A / C$, "S" for $G / C$, "R" for $A / G$ nucleotide 


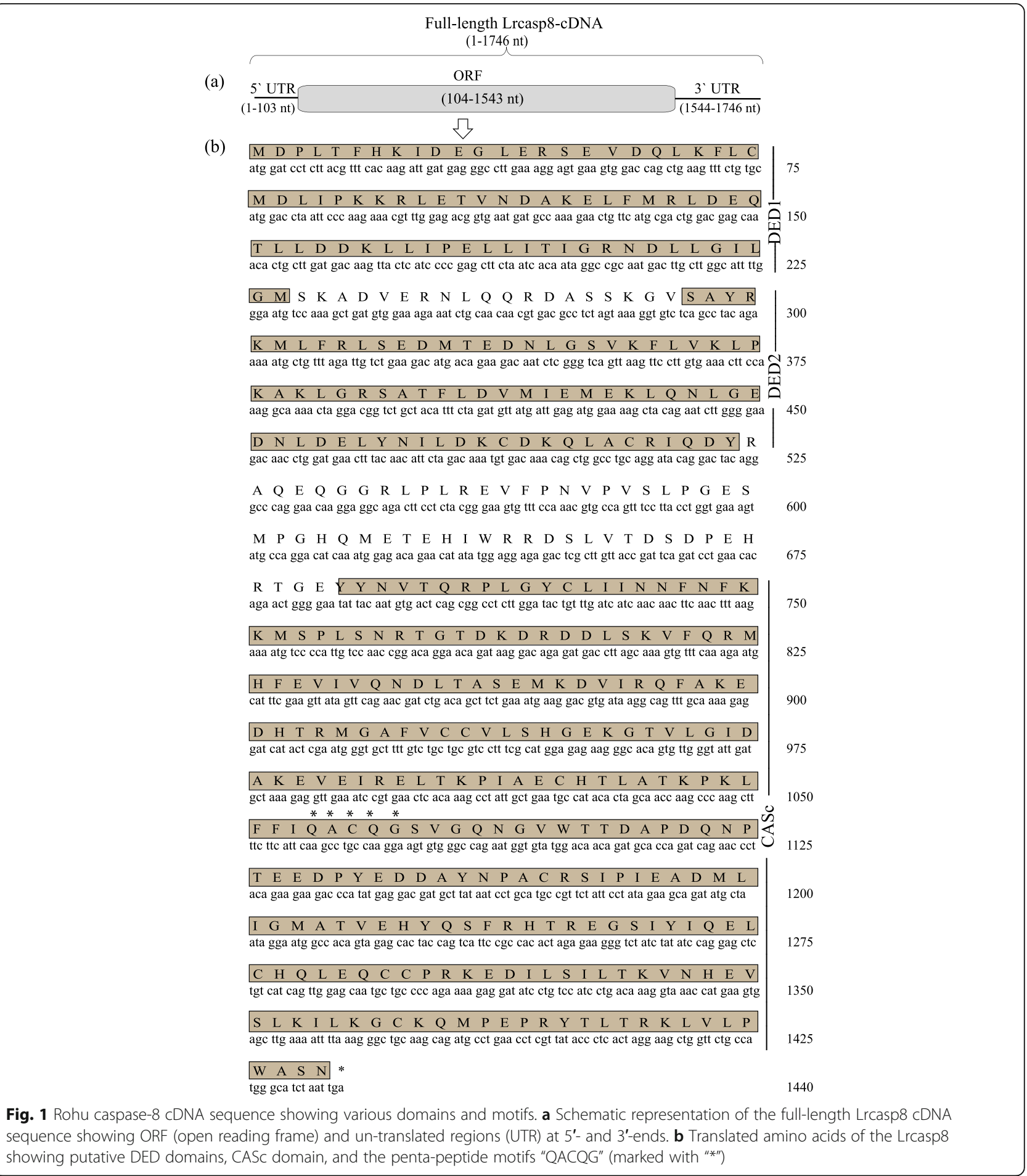

\section{Cloning of rohu caspase- 8}

To clone caspase- 8 in rohu, RNA was extracted from kidney tissue, cDNA was prepared, and the PCR was carried out with various primers (Table 1 (a)) designed from the conserved regions of caspase- 8 cDNA sequence of Danio rerio (acc. no. AF273220.1), Ctenopharyngodon idella (acc. no. KP145003.1), and
Cyprinus carpio (acc. no. KC822471.1) and also from a short transcriptome sequence of rohu caspase-8. In a $50-\mu \mathrm{l}$ PCR reaction mixture, $1 \mu \mathrm{l}$ of cDNA was used as a template and the PCR conditions were as follows: initial denaturation at $94{ }^{\circ} \mathrm{C}$ for $2 \mathrm{~min}$ followed by 40 cycles of $94{ }^{\circ} \mathrm{C} / 30 \mathrm{~s}, 55^{\circ} \mathrm{C} / 30 \mathrm{~s}$, and $72{ }^{\circ} \mathrm{C} / 45 \mathrm{~s}$, and the final extension at $72{ }^{\circ} \mathrm{C} / 10 \mathrm{~min}$. Then, $10 \mu \mathrm{l}$ of the 
(a)

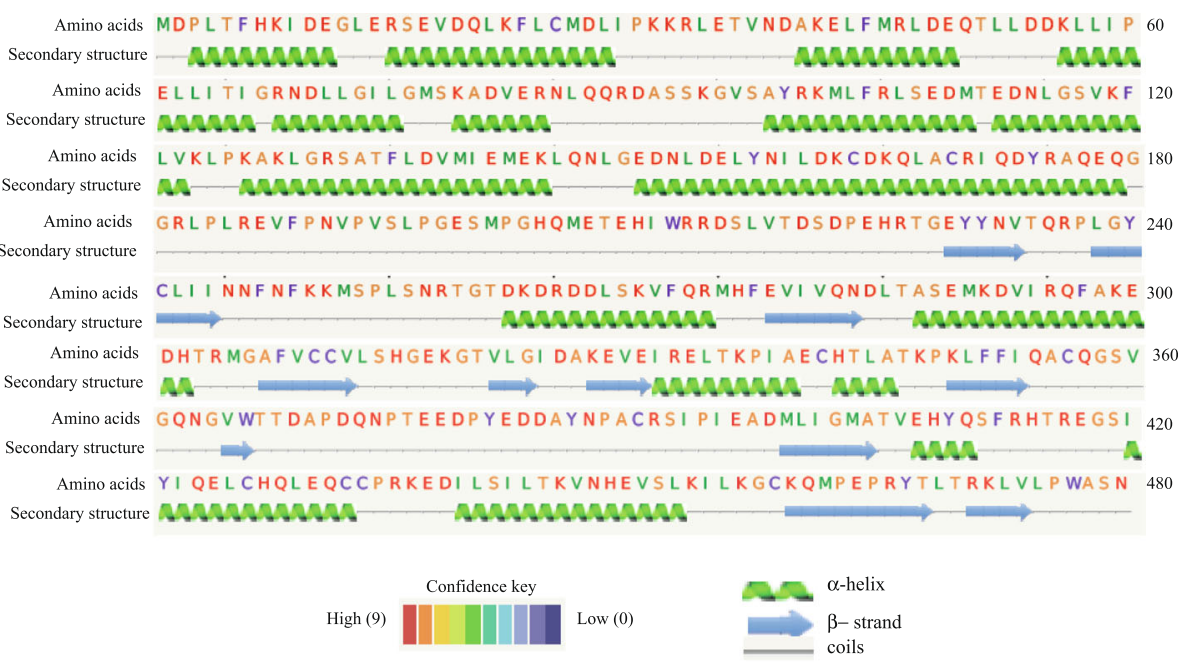

(b)

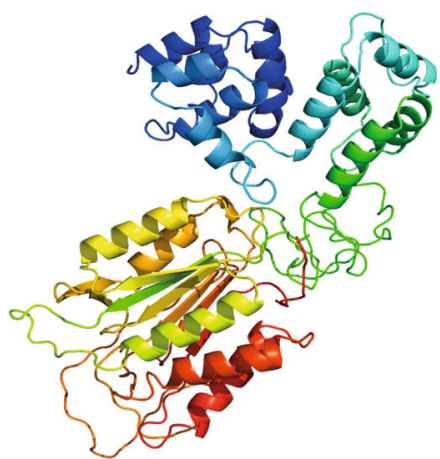

Fig. 2 Structure of Lrcasp8 protein. a The secondary structure of Lrcasp8 protein was predicted by PHYRE 2.0 program. The a-helix region is shown with "spiral," $\beta$-strands with "arrow," and the coil with "straight line." b The 3D model of Lrcasp8 was predicted by PHYRE 2.0 program. The a-helix region is shown with "spiral ribbon," $\beta$-strands with "arrow," and the connection loops with "coil"

PCR amplified products was analyzed in $2 \%$ agarose gel and specific size of the DNA band was purified from gel with gel extraction kit (QIAquick ${ }^{\bullet}$, cat no: 28704). Purified DNA was cloned into pGEM-T Easy vector (Promega, Madison, USA, cat no: A1360), and isolated plasmids from recombinant white clones were DNA sequenced (Bio serve, India Ltd, Hyderabad) with T7 and SP6 primers. The obtained sequences were analyzed by BLAST program (https://blast.ncbi. nlm.nih.gov/Blast.cgi) to confirm it as Labeo rohita caspase-8.

\section{Analysis of rohu caspase- 8 cDNA sequence}

In rohu caspase-8 full-length cDNA sequence, the ORF was detected by ORF finder (https://www.ncbi.nlm.nih.gov/orffinder/); the $\mathrm{pI}$ and $\mathrm{Mw}$ were deduced employing $\mathrm{pI} / \mathrm{Mw}$ finder (https://web.expasy.org/compute_pi/). The secondary structure and 3D model of Lrcasp8 were predicted by the protein homology/analogy recognition engine (PHYRE, V2.0) (http://www.sbg.bio.ic.ac.uk/phyre2/html/page.cgi?id= index) (Kelley et al., 2015). For the generation of the 3D model of Lrcasp8, nine templates $\{\mathrm{C} 2 \mathrm{kn} 6 \mathrm{~A}$ (structure of fulllength human asc (apoptosis-associated speck-like2 protein containing a card), c2nn3D(pro-sf-caspase-1), c5jgeA(crystal structure of caspase 8 tded), d1nw9b(Caspase catalytic domain), c2wdpA(crystal structure of ligand free human caspase-6), c5jftB(zebra fish caspase-3), d1m72a(Caspase catalytic domain), c4zbwA(crystal structure of death effector domain of caspase8 in homo sapiens), $\mathrm{c} 1 \mathrm{kmcB}$ (crystal structure of the caspase-7 / xiap-bir2 complex)\} were selected based on heuristics to maximize confidence, percentage identity, and alignment coverage of the Lrcasp8. Within the Lrcasp 8 protein, $96 \%$ of the residues have been modeled at > $90 \%$ confidence level.

The motifs/domains present in the caspase- 8 of various animal species were analyzed by SMART (http://smart.embl-heidelberg.de/) and motif scan (https://myhits.isb-sib.ch/cgi-bin/ motif_scan). To identify the similarity and identity among the amino acids of various fish species, animals, and humans, pairwise sequence alignment of the caspase- 8 protein was carried 


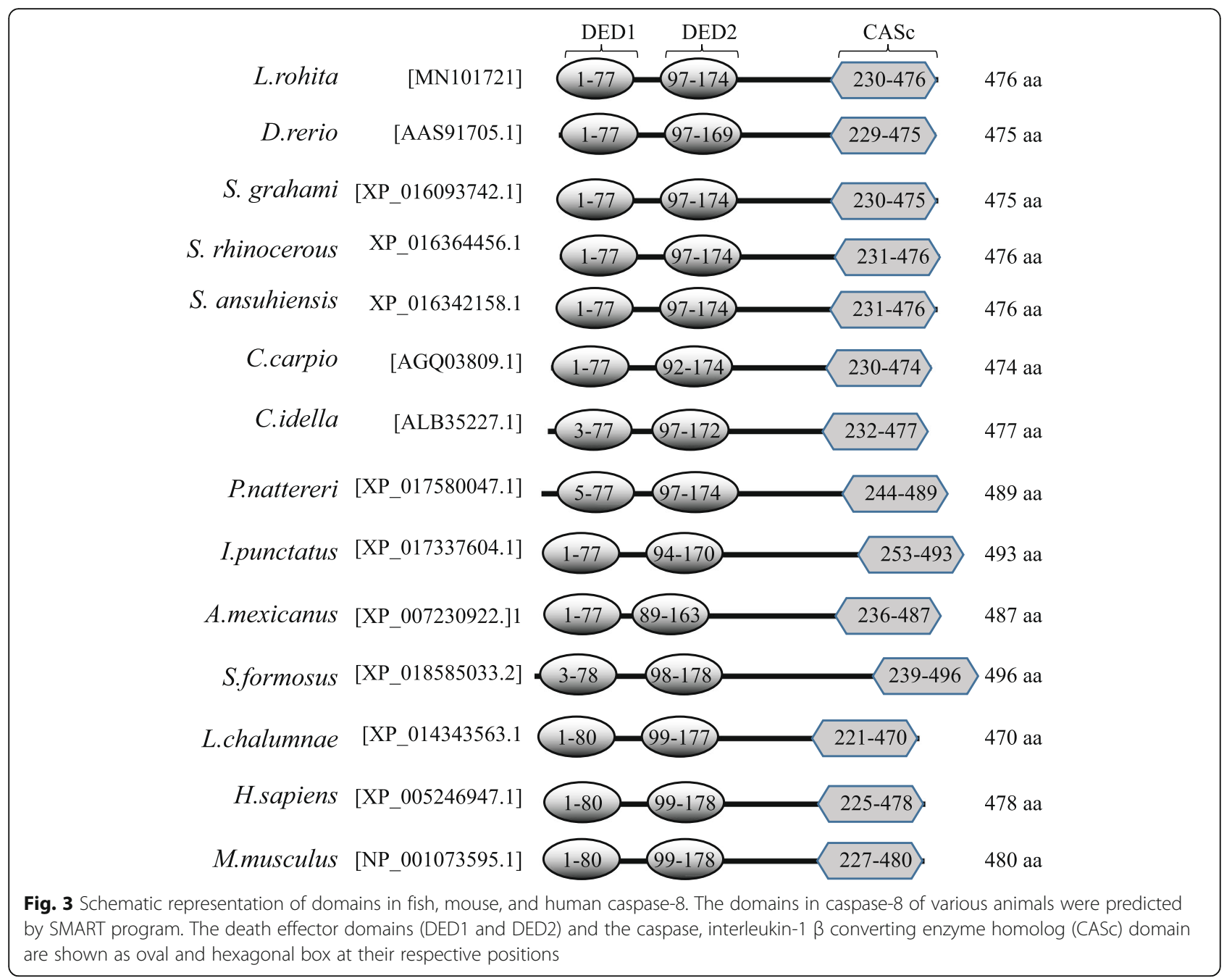

Table 2 Similarity and identity of amino acids in Lrcasp8 and its domains with other fish and animal species caspase-8

\begin{tabular}{|c|c|c|c|c|c|c|c|c|}
\hline \multirow[t]{2}{*}{ Species } & \multicolumn{2}{|l|}{ Caspase-8 } & \multicolumn{2}{|l|}{ DED1 } & \multicolumn{2}{|l|}{ DED2 } & \multicolumn{2}{|l|}{ CASC } \\
\hline & Identity (\%) & Similarity (\%) & Identity (\%) & Similarity (\%) & Identity (\%) & Similarity (\%) & Identity (\%) & Similarity (\%) \\
\hline Sinocyclocheilus grahami & 81.8 & 88.5 & 80.5 & 84.4 & 85.9 & 93.6 & 83.4 & 90.7 \\
\hline Sinocyclocheilus rhinocerous & 79.7 & 88.9 & 83.1 & 87.0 & 80.8 & 93.6 & 81.0 & 91.5 \\
\hline Sinocyclocheilus anshuiensis & 79.7 & 87.5 & 80.5 & 84.4 & 80.8 & 91.0 & 81.8 & 90.3 \\
\hline Cyprinus carpio & 78.7 & 88.3 & 75.3 & 83.1 & 83.3 & 96.2 & 82.6 & 91.5 \\
\hline Ctenopharyngodon idella & 68.9 & 80.2 & 70.1 & 79.2 & 71.8 & 88.5 & 75.7 & 84.6 \\
\hline Danio rerio & 63.6 & 76.6 & 67.5 & 79.2 & 66.7 & 78.2 & 67.6 & 80.2 \\
\hline Pygocentrus nattereri & 52.5 & 68.8 & 58.4 & 70.1 & 63.3 & 78.2 & 58.3 & 74.1 \\
\hline Ictalurus punctatus & 53.8 & 68.4 & 63.6 & 76.6 & 57.0 & 75.6 & 62.3 & 74.5 \\
\hline Astyanax mexicanus & 49.7 & 65.7 & 61.0 & 70.1 & 59.5 & 75.6 & 56.0 & 69.4 \\
\hline Scleropages formosus & 46.6 & 62.8 & 52.6 & 62.8 & 50.0 & 70.5 & 53.0 & 69.0 \\
\hline Latimeria chalumnae & 40.2 & 56.7 & 38.8 & 51.3 & 40.0 & 60.8 & 48.8 & 63.6 \\
\hline Mus musculus & 40.1 & 61 & 41.3 & 58.8 & 45.0 & 67.5 & 43.5 & 63.8 \\
\hline Homo sapiens & 39.4 & 58.7 & 37.5 & 55.0 & 42.5 & 58.8 & 44.8 & 62.6 \\
\hline
\end{tabular}




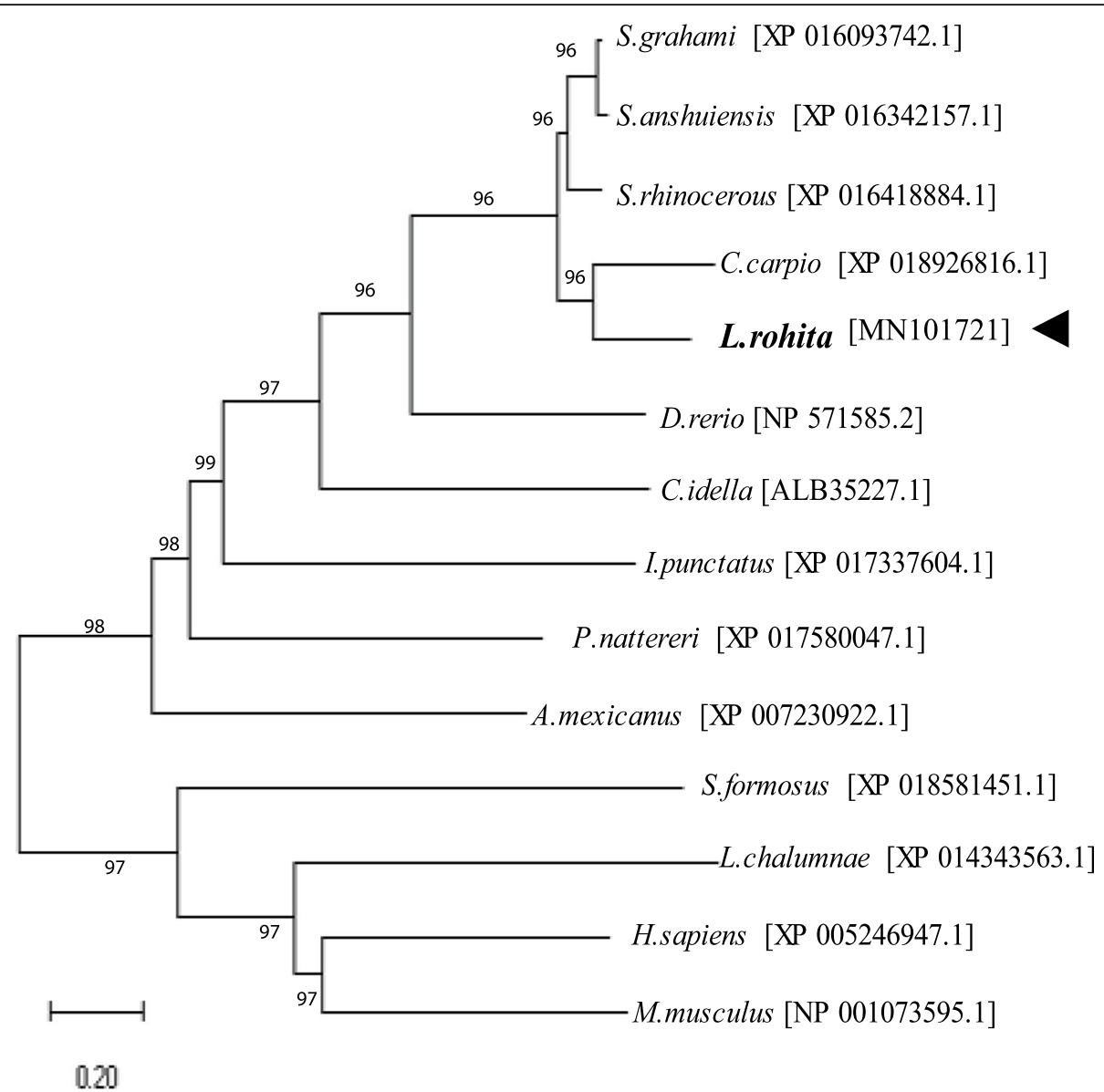

Fig. 4 Phylogenetic relationship of rohu caspase-8 with other animal species. Full-length caspase-8 amino acid sequences of various animal species were retrieved from the GenBank (acc. no. mentioned inside the bracket), and the un-rooted phylogenetic tree was generated by the neighbor-joining method within the MEGA-X program

out in the EMBOSS Needle program (https://www.ebi.ac.uk/ Tools/psa/). The phylogenetic tree was constructed with the amino acid sequences of rohu and other animal species caspase- 8 following the neighbor-joining method of the MEGA-X program (Kumar et al., 2018).

\section{Tissue-specific expression of caspase-8 gene in rohu}

To examine the basal expression of caspase- 8 gene in the immunologically related organs, the gill, liver, kidney, spleen, and blood from three healthy rohu fingerlings were collected in TRIzol reagent. Total RNA was extracted, cDNA was prepared, and the expression of caspase- 8 and $\beta$-actin gene were analyzed by the quantitative real-time PCR (qRT-PCR) assay, where $\beta$-actin was used as a housekeeping gene.

\section{Infection of LRG cells with $A$. hydrophila}

Labeo rohita gill (LRG) cells (Majeed et al., 2013) were cultured in L-15 medium containing 10\% FBS (fetal bovine serum, HiMedia lab. cat no: RM9954) and antibiotic (penicillin, $100 \mathrm{IU} / \mathrm{ml}$; streptomycin, $100 \mu \mathrm{g} / \mathrm{ml}$ ) solution. For A. hydrophila infection, $48 \mathrm{~h}$ culture of LRG cells was seeded in 6-well cell culture plates (BD Biosciences, cat no. 353046), and two wells were marked as control and four wells as treated. After $24 \mathrm{~h}$, control cells were mock infected and the treated group of cells were infected by $A$. hydrophila $\left(12 \times 10^{3} \mathrm{CFU}\right)$ at $1 \mathrm{MOI}$ (multiplicity of infection). The media were changed after $30 \mathrm{~min}$ of infection, and the status of cells (both control and treated) was observed under the microscope up to $2.30 \mathrm{~h}$ post-infection. Then, cells from the control and treated group of wells were collected in TRIzol reagent, RNA was isolated, cDNA was prepared, and the caspase- 8 gene expression in control and treated cells was analyzed by qRTPCR assay.

\section{Result}

\section{Characterization of Labeo rohita caspase-8 cDNA} sequence

The complete cDNA sequence of Lrcasp8 submitted in the GenBank with the accession number MN101721 comprised 


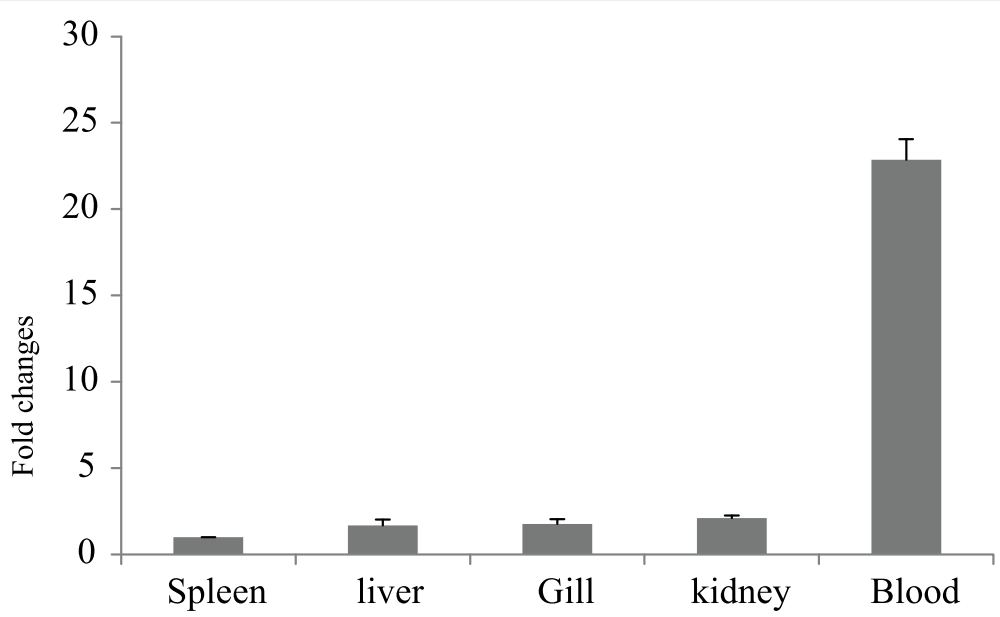

Fig. 5 Tissue-specific caspase-8 gene expression in Labeo rohita. To investigate the tissue-specific expression of caspase-8 gene, total RNA was extracted from the gill, liver, kidney, spleen, and blood of rohu fingerlings and CDNA was prepared. Employing quantitative real-time PCR (qRTPCR) assay, the cDNA of each tissue sample was analyzed for the expression of caspase- 8 and $\beta$-actin (housekeeping gene) gene expression. Expression of caspase- 8 gene in each tissue was represented as a ratio relative to $\beta$-actin levels in the same samples. The spleen was chosen as the calibrator (1), and the relative expression of caspase-8 gene in other tissues was represented as fold changes from the calibrator. The results obtained from three fish were expressed as mean \pm standard error (bars in the graph).

1746 nucleotides (nt) with the following features: 5'UTR ${ }^{103 n t}$, $\mathrm{ORF}^{1440 \text { nt }}$, and $3^{\prime} \mathrm{UTR}^{203 \mathrm{nt}}$ (Fig. 1a). The predicted Lrcasp8 protein consisted of 480aa having 5.41 isoelectric point (pI) and $54.85 \mathrm{kDa}$ molecular mass. In Lrcasp8, there were three domains: DED1 $1^{1-77 a a}, \mathrm{DED} 2^{97-174 a a}$, and $\mathrm{CASc}^{230-476 a a}$. In addition to these domains, diverse putative motifs consisting of a large subunit (p20 237-360aa $)$, a small subunit ( $\left.10^{389-474 a a}\right)$, and a penta-peptide (QACQG ${ }^{354-358 a a}$ ) active site motif were detected in the CASc domain (Fig. 1b). The secondary structure of Lrcasp8 protein consisted of seventeen $\alpha$-helices, eleven $\beta$-strands, and twenty-nine coils (Fig. 2a). The 3D model of Lrcasp8 depicting helices, strands, and coils is shown in Fig. 2b.

\section{Putative domains in rohu caspase- 8 and its relation with other animals' caspase-8}

DED1, DED2, and CASc domains and their respective positions in Lrcasp8 protein, various other fish species, mouse, and human caspase- 8 are shown in Fig. 3. The identity and similarity of amino acids present in the Lrcasp8 polypeptide, its DEDs, and CASc domains were compared with other fish species and higher vertebrate counterparts (Table 2). The amino acid sequence of Lrcasp8 shared the highest identity with Sinocyclocheilus grahami (81.8\%), followed by Sinocyclocheilus rhinocerous (79.7\%), Sinocyclocheilus anshuiensis (79.7\%), Cyprinus carpio (78.7\%), Ctenopharyngodon idella (68.9\%), and Danio rerio (63.6\%). With other fish species, the identity of the amino acids ranged between 40 and 50\%, and with human and mouse, it was $~ 40 \%$. The highest similarity was observed with Sinocyclocheilus fish species ( 87\%) followed by common carp, grass carp, and zebrafish ( 75-80\%). The lowest identity (40.2\%) and similarity $(56.2 \%)$ of the Lrcasp 8 amino acid sequence were observed with Latimeria chalumnae. The amino acid sequence of DED and CASc domains was also compared with other fish and animal species DED and CASc domains, and they showed the similar pattern of identity and similarity as observed with Lrcasp8. Among the DED1, DED2, and CASc domains, the maximum identity and similarity were observed in DED2 domain. The DED2 domain of Lrcasp8 displayed the highest identity (96.2\%) and similarity (83.3\%) with common carp and the lowest identity (42.5\%) and similarity (58.8\%) with humans.

\section{Phylogenetic relationship}

To investigate the evolutionary relationship of caspase-8, a phylogenetic tree was constructed by the pairwise alignments of Lrcasp8 amino acid sequence with various fish species, mouse, and human caspase-8 (Fig. 4). It is observed that the Lrcasp8 formed a separate group with the caspase- 8 of Sinocyclocheilus sp. and C.carpio indicating their close functional relationship. The mammalian caspase- 8 formed a separate group and was distantly related to Lrcasp8.

\section{Tissue-specific caspase- 8 gene expression}

The data of qRT-PCR revealed the basal expression of caspase- 8 gene in the gill, liver, kidney, spleen, and blood with varied intensity (Fig. 5). Among all the examined tissues, the lowest expression of caspase- 8 gene was noted in the spleen (1-fold), and compared to it, the highest expression was in the blood $(\sim 23$-fold) followed by the kidney $(\sim$ 2 -fold), gill ( 1.7-fold), and liver ( 1.5-fold). 
(a)

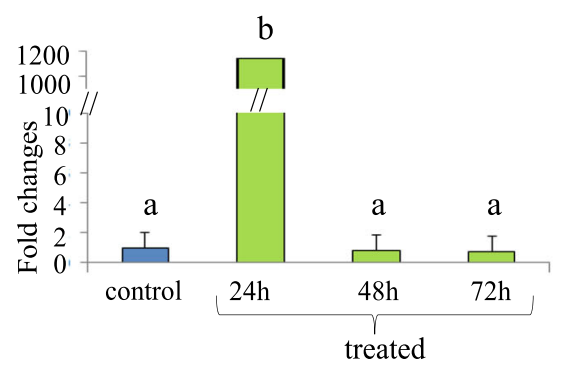

(c)

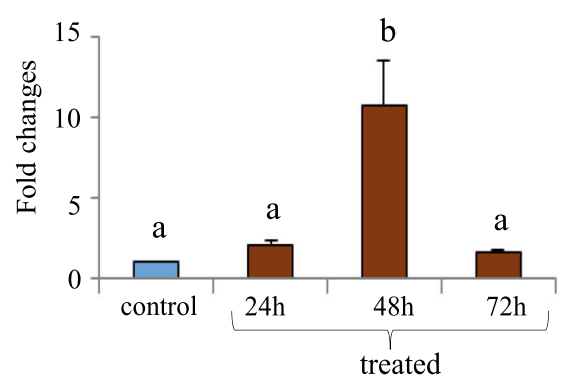

(b)

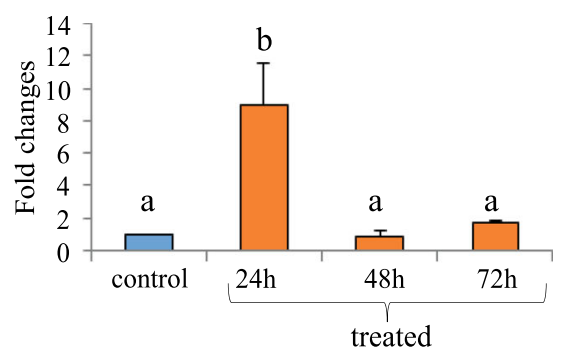

(d)

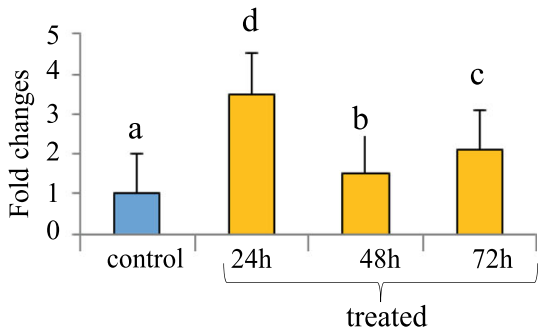

(e)

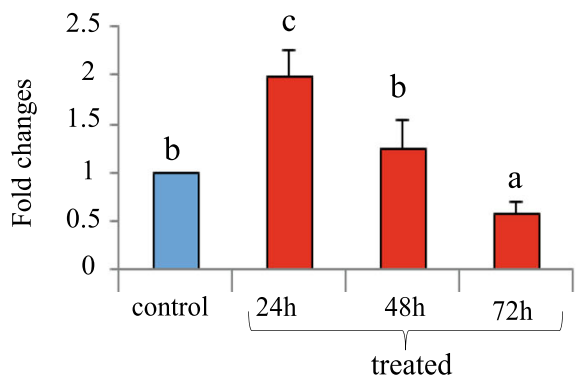

Fig. 6 Caspase-8 gene expression profile in Labeo rohita following A. hydrophila infection. Labeo rohita fingerlings ( $n=3$ ) were injected with $A$. hydrophila $\left(1 \times 10^{6} \mathrm{CFU} /\right.$ fish) by intra-peritoneal (i.p.) route. After 24, 48, and $72 \mathrm{~h}$, total RNA was extracted from the gill, liver, kidney, spleen, and blood, and then, caspase- 8 and $\beta$-actin gene expression in these tissues were analyzed by qRT-PCR. Expression of caspase- 8 gene in each tissue was normalized to the $\beta$-actin gene, and relative expression of caspase- 8 has been shown as fold changes compared to the un-treated control fish ( $n=3)$. a Gill. b Kidney. c Liver. d Spleen. e Blood

\section{Caspase- 8 gene is differentially expressed in bacterial infections}

Compared to the control, in the A. hydrophila infected fish gill, caspase- 8 gene expression was $\sim 1200$-fold at $24 \mathrm{~h}$ post-infection and it gradually decreased with the advancement of time (Fig. 6a). In the liver, caspase- 8 gene expression was $\sim 9$-, $\sim 0.4-$, and $\sim 2$-fold at 24,48 , and $72 \mathrm{~h}$, respectively (Fig. 6b). In the kidney, the highest induction ( 11-fold) was noted only at $48 \mathrm{~h}$ post-infection (Fig. 6c). In the spleen, caspase- 8 gene expression was $\sim 3.8-, \sim 1.5-$, and $\sim 2$-fold at 24, 48, and $72 \mathrm{~h}$, respectively (Fig. 6d). In the blood, the highest $(\sim 2$-fold $)$ induction of caspase- 8 gene was noted at $24 \mathrm{~h}$ post-infection and it gradually decreased over the time (Fig. 6e).
In the $E$. tarda infected fish, caspase- 8 gene expression in the gill at 24, 48, and $72 \mathrm{~h}$ post-infection was $\sim$ 2.8-fold, $\sim$ 0.8-fold, and $\sim 1.2$-fold, respectively (Fig. $7 \mathrm{a})$. In the liver, there was a marked decrease of caspase- 8 at different time points (Fig. 7b). In the kidney, highly significant $(p<0.05)$ induction $(\sim 5.8$ fold) of caspase- 8 gene was observed only at $24 \mathrm{~h}$ post-infection (Fig. 7c). In the spleen, similar trend of caspase- 8 gene expression as observed in the kidney was noted having the highest ( 10.5 -fold) induction only at 24 $\mathrm{h}$ post-infection (Fig. 7d). In the blood, induction of caspase- 8 gene expression was highest ( 1.4-fold) at $24 \mathrm{~h}$ post-infection, and then, it gradually decreased with the advancement of time (Fig. 7e). 
(a)

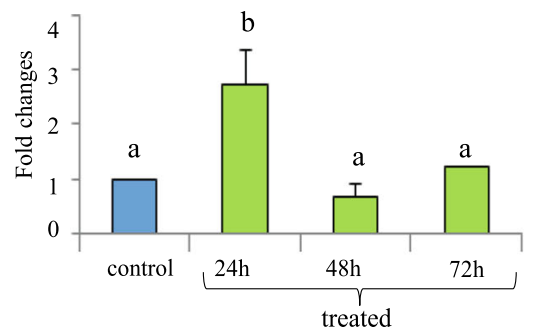

(c)

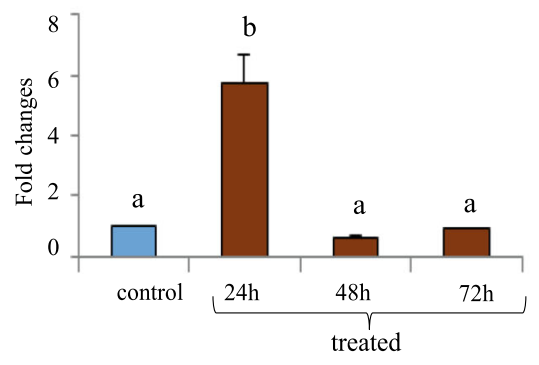

(b)

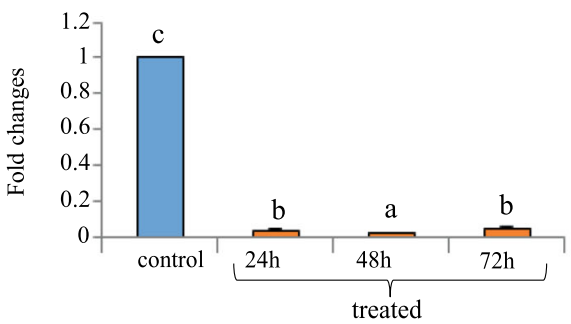

(d)

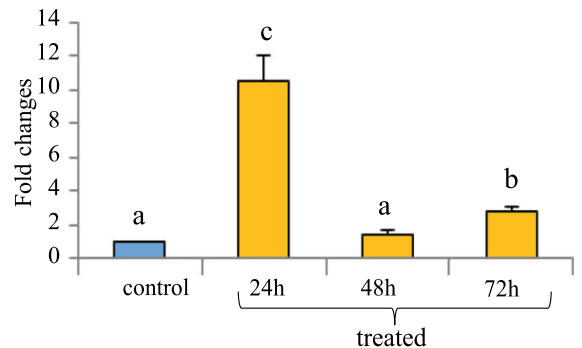

(e)

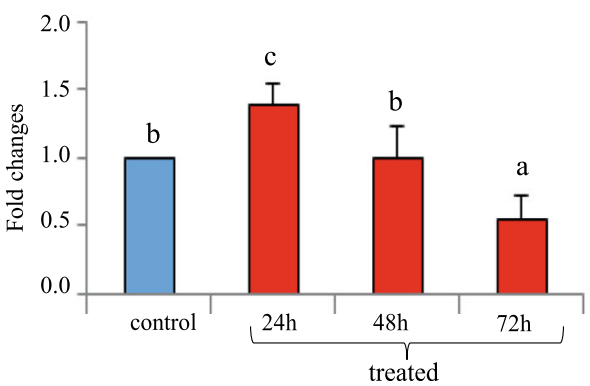

Fig. 7 Modulation of caspase-8 gene in Labeo rohita in response to $E$. tarda infection. Labeo rohita fingerlings $(n=3)$ were intra-peritoneally (i.p.) infected with E. tarda $\left(3 \times 10^{6} \mathrm{CFU} /\right.$ fish), for 24, 48, and $72 \mathrm{~h}$. Then, the gill, kidney, liver, spleen, and blood were collected from the un-infected control and E. tarda infected fish and total RNA was extracted. Following CDNA synthesis, caspase-8 and $\beta$-actin gene expression in each sample was analyzed by the qRT-PCR assay. Caspase- 8 gene expression in each tissue has been normalized to the $\beta$-actin gene (housekeeping), and relative expression of caspase- 8 gene (mean \pm standard errors (bars)) has been represented as fold changes compared to the un-treated control fish $(n=3)$. a Gill. b Liver. c Kidney. d Spleen. e Blood

\section{Modulation of caspase-8 gene expression in rhabdovirus vaccination}

In response to the rhabdovirus vaccine, caspase- 8 gene expression in the gill was found to be the highest $(\sim 2$.8-fold) only at $72 \mathrm{~h}$ post-vaccination (Fig. $8 \mathrm{a}$ ). In the liver, there was a gradual increase in caspase- 8 gene expression with the advancement of time and it reached $\sim 14$-fold at $24 \mathrm{~h}$ post-vaccination (Fig. 8b). In the kidney, caspase- 8 gene expression at 24,48 , and $72 \mathrm{~h}$ was $\sim 0.4$-fold, $\sim 1$.6-fold, and $\sim 1$-fold, respectively (Fig. $8 \mathrm{c}$ ). Among all of the tested tissues, caspase- 8 gene expression was highest $(\sim 120$ fold) in the spleen at $72 \mathrm{~h}$ (Fig. $8 \mathrm{~d}$ ). In the blood, caspase- 8 gene expression was $\sim 3.2$-fold at $24 \mathrm{~h}$ post-vaccination, and after that, it gradually decreased with the advancement of time (Fig. 8e).

\section{Expression of caspase-8 gene during cell death in $A$. hydrophila infection}

To investigate the expression of caspase- 8 gene during apoptosis and cell death, LRG cells were infected with $A$. hydrophila, and then, the cytological changes were observed under microscope and the caspase- 8 gene expression was analyzed by qRT-PCR assay (Fig. 9). The result revealed that the un-infected control LRG cells maintained their normal morphology of the epithelial cells (Fig. 9a). However, the A.hydrophilla infected LRG cells were under apoptotic changes showing shrinkage and clustering at $2 \mathrm{~h}$ (Fig. 9b), and it was much intensified at $2.30 \mathrm{~h}$ resulting in floating and initiation of cell death (Fig. 9c). The qRT-PCRanalysis revealed significant $(p<0.05)$ induction of caspase8 gene expression in the $A$. hydrophila infected cells at $2 \mathrm{~h}$ 
(a)

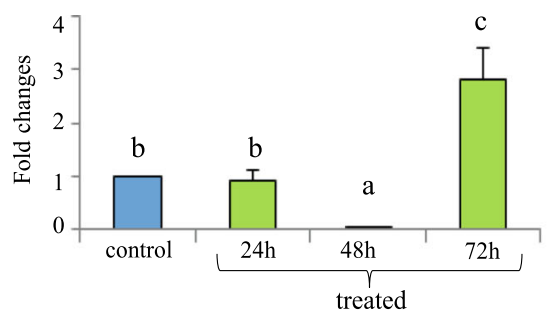

(c)

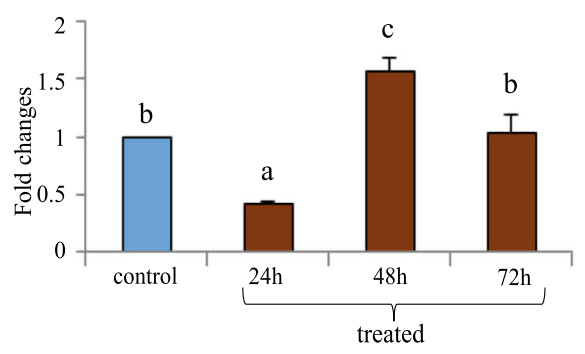

(b)

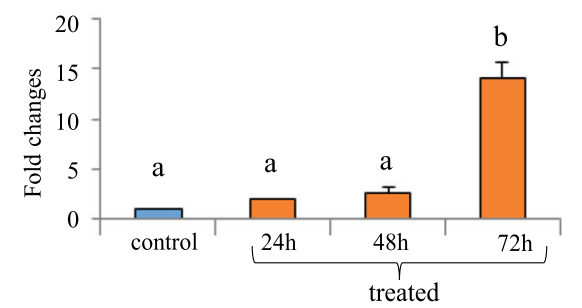

(d)

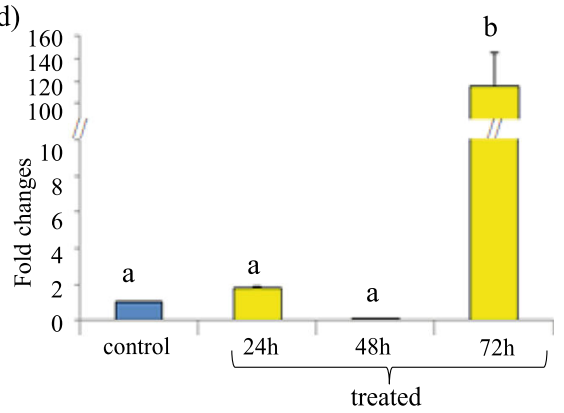

(e)

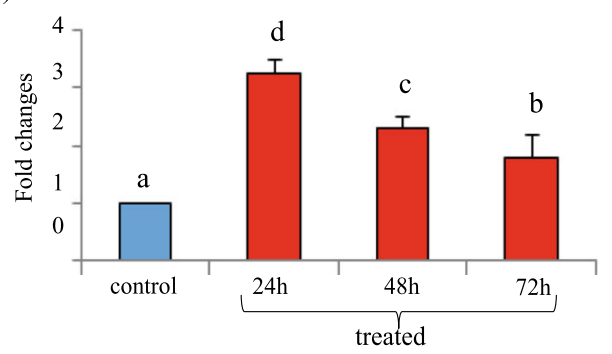

Fig. 8 Modulation of caspase-8 gene expression in rhabdovirus vaccination. Labeo rohita fingerlings $(n=3)$ were inoculated with inactivated rhabdovirus vaccine by intra-peritoneal (i.p.) route. After the designated time course, total RNA was extracted from the gill, liver, kidney, spleen, and blood and quantitative real-time PCR was employed to analyze caspase- 8 and $\beta$-actin gene expression in these tissues. Expression of caspase-8 gene in these tissues were normalized with $\beta$-actin and expressed as fold changes as compared to the un-infected control ( $n=3)$. The results are expressed as mean \pm standard errors (bars). a Gill. b Liver. c Kidney. d Spleen. e Blood

$(\sim 6.4$-fold $)$ and $2.30 \mathrm{~h}(\sim 4.2$-fold $)$ as compared to the uninfected control LRG cells.

\section{Discussion}

Apoptosis, a process of programmed cell death, is involved in host immune defense mechanism, maintenance of cellular homeostasis, embryonic development, and chemical-induced cell death and is governed by members of the family of conserved cysteine proteases called as caspases. Initially synthesized as inactive pro-caspases, caspases are quickly cleaved and activated in response to granzyme B, death receptors, and apoptosome stimuli. Activated caspases then cleave various substrates, including downstream caspases, nuclear proteins, plasma membrane proteins, and mitochondrial proteins, ultimately leading to cell death. Various pathogens cause diseases and huge mortality in Labeo rohita, a leading freshwater fish species in India and its surrounding countries. To prevent diseases, understanding the molecular pathways of disease progression and apoptosis is important. As there was no information on caspase- 8 in $L$ rohita, we undertook this study in this fish species.

Analysis of Lrcasp8-cDNA sequence through BLAST search showed significantly high (80-90\%) homology with other fish and animal species caspase-8. Similarly, SMART analysis and motif search of the Lrcasp8 peptide revealed the presence of DED domain at N-terminal and CASc domain at the $\mathrm{C}$-terminal. These are the typical architecture of caspase- 8 reported in various animal species. The pentapeptide active site motif "QACQG" as reported in other fish species caspase-8 (Reis et al., 2010; Oh et al., 2016) was also present in the CASc domain of the Lrcasp8. The presence of typical domains and motifs in Lrcasp8 suggests the functional similarity of caspase- 8 across the animal species. Phylogenetically, rohu caspase- 8 was closely related to common carp, and this was expected as rohu and common carp belong to the same family of Cyprinidae. 
(a)

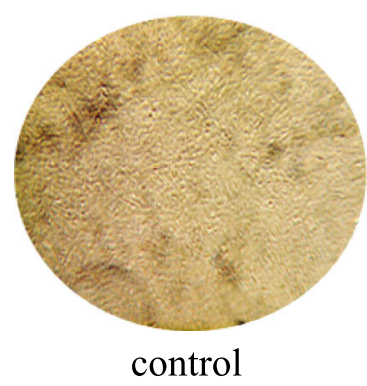

control (b)

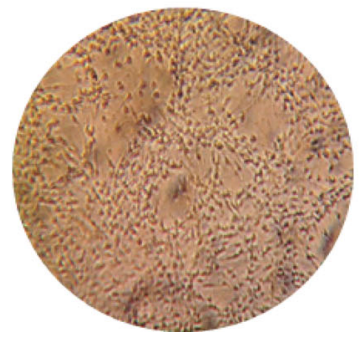

$2 \mathrm{~h} \mathrm{p.i}$ (c)

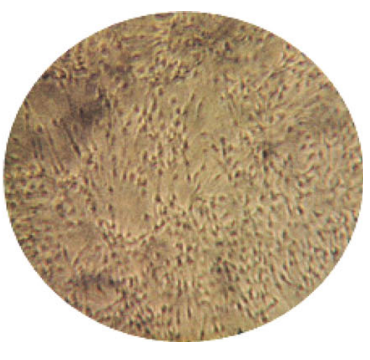

2:30 h p.i.

(d)

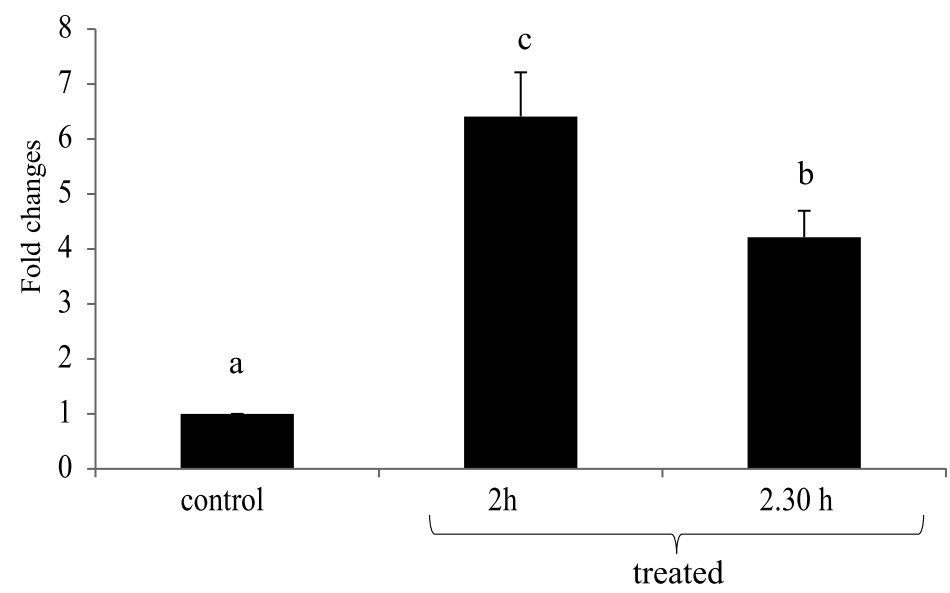

Fig. 9 Caspase-8 gene expression is induced in LRG cell line during cell death by A. hydrophila infection. Labeo rohita gill (LRG) cell line was cultured for $48 \mathrm{~h}$, and then, it was either mock infected or A. hydrophila infected (at $1 \mathrm{MOI}$ ) for $2 \mathrm{~h}$ to $2.30 \mathrm{~h}$. Then, control and treated cells were observed under microscope $(\times 10)$ to visualize the morphological changes. a Control, $\mathbf{b}$ at $2 \mathrm{~h}$, and $\mathbf{c}$ at $2.30 \mathrm{~h}$ of $\mathrm{A}$. hydrophila infection. $\mathbf{d}$ Total RNA was extracted from mock infected and A. hydrophila infected cells, and qRT- PCR was employed to investigate the expression of caspase-8 and $\beta$-actin gene. The caspase-8 gene expression has been normalized with the housekeeping gene $\beta$-actin and expressed as fold changes as compared to the control. The result has been expressed as mean \pm standard errors (bars)

In mouse, the expression of caspase- 8 gene has been reported in many organs/tissues but comparatively higher level was detected in the spleen, thymus, liver, and kidney (Sakamaki et al., 1998). In humans, similar pattern of expression of caspase- 8 gene was detected in various tissues but the highest expression was in the blood (Eckhart et al., 2001). In the sea bass, caspase-8 gene expression was almost similar in the spleen, heart, liver, intestine, and head kidney (Reis et al., 2010). In the big-belly sea horse ( $H$. abdominalis), caspase- 8 gene expression was detected in all (14 different) tested organs/ tissues, but the highest was in the ovary followed by blood (Oh et al., 2016). Similar to mouse, human, sea bass, and big-belly sea horse, the caspase- 8 gene expression in rohu was detected in all of the tested tissues and the highest expression was noted in the blood.

Stimulation of sea bass with the culture supernatants from Photobacterium damselae ssp. piscicida (Phdp) resulted in the increased expression of caspase- 8 in the spleen (Reis et al., 2010). In the blood and kidney tissue of the big-belly sea horse, significantly $(p<0.05)$ enhanced expression of caspase- 8 gene was noted following LPS stimulation and E. tarda and S. iniae infection (Oh et al., 2016). Similar to these fish species, caspase- 8 gene expression in majority of the tested organs/tissues of rohu was significantly $(p<0.05)$ enhanced following $A$. hydrophilla and E. tarda infection. In between these two bacterial species, the highest induction of caspase- 8 was noted in A. hydrophila, and it may be due to its high virulence and pathogenicity to rohu as compared to the E. tarda.

Several fish species of various family are largely infected with the members of the rhabdoviridae family such as viral hemorrhagic septicemia virus (VHSV), spring viremia of carp virus (SVCV), infectious hematopoietic necrosis virus (IHNV), pike fry rhabdovirus (PRV), hirame rhabdovirus 
(HIRRV), starry flounder virus and ulcerative disease rhabdovirus (UDRV), and snakehead rhabdovirus (SHRV) (Mork et al., 2004; Walker et al., 2018). Among these members of the rhabdovrus family, SVCV, VHSV, and IHNV are reported as fatal fish pathogens causing enormous morbidity and huge mortality in the wild and cultured fish (Bootland et al., 1999). Although, SVCV primarily affects fishes of the Cyprinidae family (Ahne et al., 2002) but VHSV infects a variety of fish species belonging to various families (Al-Hussinee et al., 2011). To investigate the response of caspase- 8 gene in rhabdovirus infections, rohu fingerlings were injected with an inactivated rhabdovirus vaccine of animals containing RNA viral genome (Basu et al., 2016; Banerjee et al., 2017). The result showed significant $(p<0.05)$ increase in caspase- 8 gene expression in all tested organs, and the most significant induction was noted in the spleen at $72 \mathrm{~h}$ post-injection. In the big-belly sea horse, poly I:C, a double-stranded RNA mimicking molecule, also induced caspase- 8 gene expression in the blood and kidney (Oh et al., 2016). The supernatant of Phdp was reported to induce apoptosis and the induction of caspase- 8 in sea bass macrophages and neutrophils (Reis et al., 2010). Similar to the sea bass, in the gill cell line of Labeo rohita (LRG), caspase-8 gene expression was also enhanced following $A$. hydrophila infection and cell death. Together, these data suggest the existence of a common apoptotic pathway contributed by caspase- 8 in fish as reported in higher vertebrates.

\section{Conclusions}

In this article, we report the identification and molecular characterization of caspase- 8 , an important member of the caspase family in initiating the apoptotic death-signaling cascades in Labeo rohita, a fish species of highest commercial importance in India and its surrounding countries. Structurally, Lrcasp8 protein comprised "DED" and "CASc" domains and the secondary structure revealed seventeen $\alpha$ helices, eleven $\beta$-strands, and twenty-nine coils showing its evolutionary conserved relationship with the caspase- 8 of other vertebrates. In response to $A$. hydrophila and E. tarda infections and rhabdovirus vaccinations, caspase- 8 gene expression in $L$. rohita was significantly enhanced in most of the tested organs/tissues suggesting its important role in pathogenic invasions and apoptosis.

\footnotetext{
Abbreviations

CASc: Carboxyl-terminal catalytic domain; CDNA: Complementary DNA; DED: Death effector domain; DISC: Death-inducing signaling complex; FADD: Fas-associated protein with death domain; FBS: Fetal bovine serum; LB: Luria-Bertani; LRG: Labeo rohita gill; NF-KB: Nuclear factor kappa-B; ORF: Open reading frame; qRT-PCR: Quantitative real-time PCR; SMART: Simple Modular Architecture Research Tool; UTR: Un-translated region
}

\section{Acknowledgements}

The authors express their sincere gratitude to the Director, ICAR-CIFA, and the HOD, FHMD, ICAR-CIFA, for the research facility.
Availability of the data and materials

The data and the materials will be made available on request.

\section{Authors' contributions}

Mrinal Samanta conceptualized the work, analyzed the data, and wrote the manuscript. Alok Kumar Giri conducted the experiments of partial cloning and real-time PCR. Mahismita Paichha contributed to the RACE-cloning and RT-PCR. Pushpa Choudhary contributed to the RACE-cloning and manuscript preparation. Ashis Saha contributed to the data analysis including statistical applications. All authors read and approved the final manuscript.

\section{Funding}

This work was funded by the grant of the ICAR-National Agricultural Science Fund (ICAR-NASF-project code: NASF/ BS-4003) of the Government of India.

Ethics approval and consent to participate

The ethics statement has been written under the "Materials and methods" section.

\section{Consent for publication}

All authors have given their consent for publication.

\section{Competing interests}

All authors declare that they have no competing interests.

Received: 16 December 2019 Accepted: 17 March 2020

Published online: 15 April 2020

\section{References}

Ahne, W., Bjorklund, H. V., Essbauer, S., Fijan, N., Kurath, G., \& Winton, J. R. (2002) Spring viremia of carp (SVC). Diseases of Aquatic Organisms, 52(3), 261-272.

Al-Hussinee, L., Lord, S., Stevenson, R. M., Casey, R. N., Groocock, G. H., Britt, K. L., . Lumsden, J. S. (2011). Immunohistochemistry and pathology of multiple Great Lakes fish from mortality events associated with viral hemorrhagic septicemia virus type IVb. Diseases of Aquatic Organisms, 93(2), 117-127.

Ashkenazi, A. (2008). Targeting the extrinsic apoptosis pathway in cancer. Cytokine and Growth Factor Reviews., 19(3-4), 325-331.

Banerjee, R., Patel, B., Basu, M., Lenka, S. S., Paicha, M., Samanta, M., \& Das, S. (2017). Molecular cloning, characterization and expression of immunoglobulin D (lgD) on pathogen challenge and PAMPs stimulation in freshwater carp, Catla catla. Microbiology and immunology, 61, 452-458.

Basu, M., Lenka, S. S., Paichha, M., Swain, B., Patel, B., Banerjee, R., ... Samanta, M. (2016). Immunoglobulin (lg) D in Labeo rohita is widely expressed and differentially modulated in viral, bacterial and parasitic antigenic challenges. Veterinary immunology and immunopathology, 179, 77-84.

Bootland, L. M., \& Leong, J. C. (1999). Infectious haematopoietic necrosis virus. In P. T. K. Woo, \& D. W. Bruno (Eds.), Fish diseases and disorders, (vol. 3, pp. 57121). Wallingford: $C A B$ International.

Eckhart, L., Henry, M., Santos-Beneit, A. M., Schmitz, I., Krueger, A., Fischer, H., ... Tschachler, E. (2001). Alternative splicing of caspase-8 mRNA during differentiation of human leukocytes. Biochemical and biophysical research communications, 289, 777e81.

Jost, P. J., Grabow, S., Gray, D., McKenzie, M. D., Nachbur, U., Huang, D. C., .. Kaufmann, T. (2009). XIAP discriminates between type I and type II FASinduced apoptosis. Nature, 460(7258), 1035-1039.

Kawahara, A., Ohsawa, Y., Matsumura, H., Uchiyama, Y., \& Nagata, S. (1998). Caspase-independent cell killing by Fas-associated protein with death domain. The Journal of cell biology, 143, 1353-1360.

Kelley, L. A., Mezulis, S., Yates, C. M., Wass, M. N., \& Sternberg, M. J. (2015). The Phyre2 web portal for protein modeling, prediction and analysis. Nature protocols, 10(6), 845-858.

Kerr, J. F., Wyllie, A. H., \& Currie, A. R. (1972). Apoptosis (a basic biological phenomenon with wide-ranging implications in tissue kinetics). British Journal of Cancer, 26, 239-257.

Kischkel, F. C., Hellbardt, S., Behrmann, I., Germer, M., Pawlita, M., Krammer, P. H., \& Peter, M. E. (1995). Cytotoxicity-dependent APO-1 (Fas/CD95)-associated proteins form a death-inducing signaling complex (DISC) with the receptor. The EMBO Journal, 14, 5579-5588.

Kumar, S., Stecher, G., Li, M., Knyaz, C., \& Tamura, K. (2018). MEGA X: Molecular Evolutionary Genetics Analysis across computing platforms. Molecular Biology and Evolution, 35, 1547-1549. 
Kuwana, T., Smith, J. J., Muzio, M., Dixit, V., Newmeyer, D. D., \& Kornbluth, S. (1998). Apoptosis induction by caspase- 8 is amplified through the mitochondrial release of cytochrome C. The Journal of Biological Chemistry, 273(26), 16589-16594.

Li, P., Nijhawan, D., Budihardjo, I., Srinivasula, S. M., Ahmad, M., \& Alnemri, E. S. (1997). Cytochrome $\mathrm{C}$ and dATP-dependent formation of Apaf-1/caspase-9 complex initiates an apoptotic protease cascade. Cell, 91(4), 479-489.

Livak, K. J., \& Schmittgen, T. D. (2001). Analysis of relative gene expression data usingreal-time quantitative PCR and the 2(-Delta Delta C (T)) Method. Methods, 25(4), 402-408.

Luo, X., Budihardjo, I., Zou, H., Slaughter, C., \& Wang, X. (1998). Bid, a Bcl2 interacting protein, mediates cytochrome $\mathrm{C}$ release from mitochondria in response to activation of cell surface death receptors. Cell, 94(4), 481-490.

Maelfait, J., \& Beyaert, R. (2008). Non-apoptotic functions of caspase-8. Biochemical Pharmacology, 76(11), 1365-1373.

Majeed, A. S., Nambi, K. S., Taju, G., Raj, S. N., Madan, N., \& Hameed, A. S. (2013). Establishment and characterization of permanent cell line from gill tissue of Labeo rohita (Hamilton) and its application in gene expression and toxicology. Cell Biology and Toxicology, 29(1), 59-73.

Mork, C., Hershberger, P., Kocan, R., Batts, W., \& Winton, J. (2004). Isolation and characterization of a rhabdovirus from starry flounder (Platichthys stellatus) collected from the northern portion of Puget Sound, Washington, USA. Journal of General Virology, 85, 495-505.

Oh, M., Elvitigala, D. A., Bathige, S. D., Lee, S., Kim, M. J., \& Lee, J. (2016). Molecular and functional characterization of caspase- 8 from the big-belly seahorse (Hippocampus abdominalis). Fish and Shellfish Immunology, 58, 650-662.

Reis, M. I., Costa-Ramos, C., do Vale, A., \& dos Santos, N. M. (2010). Molecular cloning of sea bass (Dicentrarchus labrax L.) caspase- 8 gene and its involvement in Photobacterium damselae ssp. piscicida triggered apoptosis. Fish and Shellfish Immunology, 29(1), 58-65.

Sadangi, S., Mohanty, A., Paichha, M., Gouda, S., Saha, A., Das, S., \& Samanta, M. (2020). Molecular characterization and expressional modulation of IRAK1 as downstream signaling adaptor molecule of TLR-signaling pathways in Labeo rohita following PAMPs stimulation and bacterial infections. Fish Shellfish Immunol, 96, 161-176.

Sakamaki, K., Nozaki, M., Kominami, K., \& Satou, Y. (2007). The evolutionary conservation of the core components necessary for the extrinsic apoptotic signaling pathway, in Medaka fish. BMC Genomics, 8, 141.

Sakamaki, K., S-i, T., \& Yonehara, S. (1998). Molecular cloning and characterization of mouse caspase-8. European Journal of Biochemistry, 253, 399e405.

Salvesen, G. S., \& Dixit, V. M. (1997). Caspases: intracellular signaling by proteolysis. Cell, 91(4), 443-446.

Shin-ichi, S., YiLin, Y., Yutaka, S., Akihiro, M., Phuong, N. H., Masami, N., ... Kazuhiro, S. (2007). Conserved function of caspase-8 in apoptosis during bony fish evolution. Gene, 396(1), 134-148.

Spead, O., Verreet, T., Donelson, C. J., \& Poulain, F. E. (2018). Characterization of the caspase family in zebrafish. PLoS ONE, 13(5), e0197966. https://doi.org/10. 1371/journal.pone.0197966.

Sun, S., Ge, X., Zhu, J., Zhang, W., \& Zhang, Q. (2015). Molecular cloning, immunohistochemical localization, characterization and expression analysis of caspase-8 from the blunt snout bream (Megalobrama amblycephala) exposed to ammonia. Fish and Shellfish Immunology, 47(2), 645-654.

Takle, H., \& Andersen, Ø. (2007). Caspases and apoptosis in fish. Journal of Fish Biology, 71, 326-349.

Teitz, T., Wei, T., Valentine, M. B., Vanin, E. F., Grenet, J., Valentine, V. A., ... Kidd, V. J. (2000). Caspase 8 is deleted or silenced preferentially in childhood neuroblastomas with amplification of MYCN. Nature Medicine, 6(5), 529-535.

Walker, P. J., Blasdell, K. R., Calisher, C. H., Dietzgen, R. G., Kondo, H., Kurath, G., .. Whitfield, A. E. (2018). ICTV Virus Taxonomy Profile: Rhabdoviridae. Journal of General Virology, 99(4), 447-448.

\section{Publisher's Note}

Springer Nature remains neutral with regard to jurisdictional claims in published maps and institutional affiliations.

\section{Submit your manuscript to a SpringerOpen ${ }^{\circ}$ journal and benefit from:}

- Convenient online submission

- Rigorous peer review

- Open access: articles freely available online

- High visibility within the field

- Retaining the copyright to your article

Submit your next manuscript at $\boldsymbol{\nabla}$ springeropen.com 